\title{
Ultrasensitive measurement of both SARS-CoV2 RNA and serology from saliva
}

Dmitry Ter-Ovanesyan $^{1 \pi}$, Tal Gilboa ${ }^{1,2 \pi}$, Roey Lazarovits ${ }^{1 \pi}$, Alexandra Rosenthal ${ }^{2}, X u$ G. Yu ${ }^{2,3,4,5}$, Jonathan Z. Li ${ }^{2,4}$, George M. Church ${ }^{1,4}$, David R. Walt ${ }^{1,2,4^{*}}$

1 - Wyss Institute for Biologically Inspired Engineering

2 - Brigham and Women's Hospital

3 - Massachusetts General Hospital

4 - Harvard Medical School

5 - Ragon Institute of MGH, MIT, and Harvard

II - These authors contributed equally to this work

${ }^{*}$ Corresponding author

Email: dwalt@bwh.harvard.edu

\begin{abstract}
:
Tests for COVID-19 generally measure SARS-CoV2 viral RNA from nasal swabs or antibodies against the virus from blood. It has been shown, however, that both viral particles and antibodies against those particles are present in saliva, which is more accessible than both swabs and blood. We present methods for highly sensitive measurements of both viral RNA and serology from the same saliva sample. We developed an efficient saliva RNA extraction method and combined it with an ultrasensitive serology test based on Single Molecule Array (Simoa) technology. We apply our test to the saliva of patients who presented to the hospital with COVID-19 symptoms, some of whom tested positive with a conventional RT-qPCR nasopharyngeal swab test. We demonstrate that combining viral RNA detection by RT-qPCR with serology identifies more patients as infected than either method alone. Our results suggest the utility of combining viral RNA and serology testing from saliva, a single easily accessible biofluid.
\end{abstract}


medRxiv preprint doi: https://doi.org/10.1101/2021.01.25.21249679; this version posted January 26, 2021. The copyright holder for this preprint (which was not certified by peer review) is the author/funder, who has granted medRxiv a license to display the preprint in perpetuity.

It is made available under a CC-BY-NC-ND 4.0 International license .

\section{Introduction:}

The two main tests for SARS-CoV2 infection are molecular tests to detect the presence of the virus (RNA or antigen) and serological tests to detect the presence of antibodies against the virus ${ }^{1-6}$. Both tests have advantages and disadvantages. RT-qPCR, the main diagnostic test and current gold standard, is a sensitive method for measuring the presence of viral RNA, usually performed from nasopharyngeal (NP) or anterior nasal swabs ${ }^{1-3}$. However, it has been shown that not all patients who are infected with SARS-CoV2 test positive for viral RNA ${ }^{1,2,5,7-9}$. There are several potential reasons for this: low viral load, variability in swabbing, or late swab collection relative to the time of infection ${ }^{2,5}$. The time at which the swab is performed is important because, after initial infection, levels of virus sharply rise and then drop, providing a relatively narrow window at which viral RNA is present ${ }^{1,5,6,10-18}$. Serology tests detect antibodies that develop against the virus during infection ${ }^{1,6}$. These antibodies remain stable for at least several months, widening the time window of testing for SARS-CoV2 infection ${ }^{19-21}$. Combining RNA detection with serology testing has the potential to increase the sensitivity of RT-qPCR alone ${ }^{6,12,20,22-26}$ by reducing false negatives in RT-qPCR.

RT-qPCR tests for SARS-CoV2 mostly analyze RNA from nasal swabs, while serology tests are generally performed using blood ${ }^{1,22,27-29}$. However, studies have shown that both SARS-CoV2 viral RNA ${ }^{12,30-33}$ and antibodies ${ }^{19,30,34}$ against the virus are present in saliva. Since saliva is easier to collect than either swabs or blood, its accessibility makes it an ideal biofluid for widespread diagnostic use. Research is still ongoing regarding how well saliva correlates to different types of swabs in terms of sensitivity of viral RNA detection ${ }^{30-32,35,36}$. This will depend largely on several factors such as patient selection, sample collection, and RNA extraction methodology. Nonetheless, it is clear that SARS-CoV2 viral RNA can be readily detected in saliva ${ }^{12,30-32}$. Similarly, previous studies have shown a strong correlation between antibodies against SARS-CoV2 in blood and saliva ${ }^{19,30,34,37-39}$.

Although RT-qPCR is highly sensitive, there is great variability in the RNA extraction efficiency, which is generally performed using commercial kits. These kits have advantages in terms of ease, but are prone to supply chain limitations ${ }^{40}$. Furthermore, using kits may lead to incompatibilities with upstream or downstream steps since the components are unknown to the user. Lastly, kits are not optimized for specific biofluids such as saliva, leading to potentially low RNA recovery. Serology testing in saliva also presents challenges; namely, that concentrations of antibodies in saliva are much lower than they are in blood ${ }^{19,30,34}$ and that different isotypes may be present in the different fluids. 
medRxiv preprint doi: https://doi.org/10.1101/2021.01.25.21249679; this version posted January 26, 2021. The copyright holder for this preprint (which was not certified by peer review) is the author/funder, who has granted medRxiv a license to display the preprint in perpetuity.

It is made available under a CC-BY-NC-ND 4.0 International license .

We set out to develop a highly sensitive test to detect both viral RNA and antibodies against the virus from the same saliva sample. We developed an optimized RNA extraction protocol that is highly efficient for saliva. We also adapted a Single Molecule Array ${ }^{41}$ (Simoa)based ultrasensitive serology test we previously developed for detecting SARS-CoV2 antibodies in blood for use in saliva ${ }^{7,42}$. Combining our RNA extraction protocol for RT-qPCR with this ultrasensitive serology test, we are able to better classify COVID-19 patients as being actively or previously infected with SARS-CoV2, demonstrating the utility of this approach for accurate diagnosis of COVID19.

\section{Results:}

In order to develop a highly sensitive test for both SARS-CoV2 RNA and serology using saliva (schematically presented in Figure 1), we first optimized the RNA extraction. We developed two versions: a low-volume version (30 $\mathrm{L}$ saliva) that can be performed in a 96 -well PCR plate and a high-volume version $(300 \mu \mathrm{L}$ saliva) that can be performed in a deep-well plate. We started with a general method based on binding nucleic acids to carboxylated paramagnetic beads in the presence of a guanidinium thiocyanate lysis buffer (Figure 2a), and optimized each step of the protocol using saliva samples. To evaluate our extraction method, we spiked in known amounts of synthetic SARS-CoV2 RNA or heat-inactivated SARS-CoV2 viral particles into PBS or human saliva and then quantified recovery after RNA extraction by RT-qPCR. (Figure 2a, Supplementary Figure 1). We tested a large number of parameters using this approach until we arrived at a protocol that consistently resulted in 50-100\% recovery in $30 \mu \mathrm{L}$ of saliva (Figure $2 b$ ). To maximize sensitivity, we opted to use more saliva $(300 \mu \mathrm{L})$ in a deep-well plate format. However, as it is difficult to elute into a small volume using a deep well plate, we included a transfer step in our protocol where we transfer the beads (during a $70 \%$ ethanol wash step) from a deep-well plate to a PCR plate, allowing us to elute the RNA in only $10 \mu \mathrm{L}$ (Figure 2a).

To see how our protocol compares to a commonly used commercial kit, we performed a head-to-head comparison with the ThermoFisher Scientific MagMAX Viral/Pathogen Nucleic Acid Isolation kit. We first extracted RNA from equal volumes of saliva spiked with viral particles and eluted the captured RNA into equal volumes (Figure 2c). In this comparison, we found that our custom protocol had more than twice the recovery of MagMAX. We also compared our protocol to MagMAX using the maximum input volume and minimum elution volumes for both protocols using saliva with the same concentration of viral particles. In this case, our protocol recovered 16x more RNA (Figure 2d). We then compared our protocol to three recently 
medRxiv preprint doi: https://doi.org/10.1101/2021.01.25.21249679; this version posted January 26, 2021. The copyright holder for this preprint (which was not certified by peer review) is the author/funder, who has granted medRxiv a license to display the preprint in perpetuity. It is made available under a CC-BY-NC-ND 4.0 International license .

developed protocols for measuring RNA from saliva without purification. These protocols, SalivaDirect ${ }^{43}$, TCEP inactivation ${ }^{44}$, and $95^{\circ} \mathrm{C}$ heating ${ }^{45}$, all use a small volume of saliva $(<10 \mu \mathrm{L})$ since the final volume of RT-qPCR reactions is usually $20 \mu \mathrm{L}$. We compared our high-volume RNA extraction to these three protocols using saliva containing the same concentration of viral particles. We found that we detected significantly more RNA in extraction-based protocols, largely due to the ability to use larger volumes of saliva (Figure $2 \mathrm{~d}$ ).

After validation of our RNA extraction protocol, we turned to combining RNA detection with serology in clinical saliva samples from COVID-19 patients. We have previously developed Single Molecule Array (Simoa) based ultrasensitive profiling of $\lg G$, IgM, and $\lg A$ antibodies against SARS-CoV2 nucleocapsid (N), spike (S), S1, and RBD protein targets in blood ${ }^{7}$. Our assay employs a bead-based, digital ELISA for high-throughput, automated ultrasensitive detection of antibodies in small volumes. Using only $40 \mu \mathrm{L}$ of saliva per sample $(10 \mu \mathrm{L}$ for serology and $30 \mu \mathrm{L}$ for RNA), we characterized 12 antibody interactions and quantified SARSCoV2 RNA across 18 saliva samples. We tested two pre-pandemic saliva samples from healthy individuals, and 16 samples from symptomatic individuals who visited the MGH Respiratory Infection Clinic during the pandemic (see SI Table S1 for clinical characteristics summary). The patients were all tested by RT-qPCR from NP swab samples upon arrival to the clinic and saliva was collected on the same day.

Combined measurement of SARS-CoV2 RNA and IgG, IgM and IgA levels against S1 (Figure 3a) revealed that five patients were positive for either RNA, serology, or both, in saliva compared to three patients by NP RT-qPCR alone. Two patients with positive serology in saliva but negative RT-qPCR (in both NP swabs and saliva) displayed severe respiratory illness, and thus likely received false negative RT-qPCR results. RNA was detected in saliva for two of the three patients with positive NP swabs. For the patient with RNA detected in the NP swab but not saliva, antibody levels were above the threshold for $\lg \mathrm{A}$ and $\lg \mathrm{M}$ against $\mathrm{S} 1$. Since our previous work showed that IgA - S1 displayed the best separation between positives and controls, this sample would be classified as positive in our serological assay. We also measured saliva from a subset of the patients at six late time points ( $>9$ days after the first positive PCR). We found no RNA was detected but antibody levels were high for most of the immunoglobulin subtypes we measured, as expected (Figure 3b). Finally, to see if we could achieve multiplexed detection of viral RNA and serology on the same platform from one sample, we developed a Simoa assay for the direct detection of SARS-CoV2 RNA. Although we found this assay to be less sensitive than RT-qPCR, the Simoa assay detects RNA without amplification. We combined this assay 
medRxiv preprint doi: https://doi.org/10.1101/2021.01.25.21249679; this version posted January 26, 2021. The copyright holder for this preprint (which was not certified by peer review) is the author/funder, who has granted medRxiv a license to display the preprint in perpetuity.

It is made available under a CC-BY-NC-ND 4.0 International license .

with our serology assay to detect RNA and antibodies spiked into saliva samples (SI Figure S3, Table S2), demonstrating multiplexed detection of RNA and serology on the Simoa platform.

\section{Discussion:}

SARS-CoV2 infection is currently diagnosed with RT-qPCR from NP swabs and the immune response is monitored using serology tests from blood or plasma samples ${ }^{1,3,4}$. Several studies have shown that saliva is suitable for both SARS-CoV2 viral RNA detection and serology measurements, but these measurements have not been made together using the same sample. In this study, we combined RT-qPCR with serology measurements on a small number of symptomatic COVID-19 patient saliva samples. We demonstrate that combining these measurements identifies SARS-CoV2 infection in patients that RT-qPCR alone misses, providing information that can help guide clinical decision making. This is particularly important in patients who present to the hospital with COVID-19 symptoms but have negative RT-qPCR results despite having been infected with SARS-CoV2 (for example because the immune system has already cleared the virus).

To maximize sensitivity of RNA detection, we developed and optimized a high-efficiency saliva RNA extraction protocol without the use of kits. We found our protocol yields much higher levels of RNA from saliva than a widely-used commercial isolation kit when performed manually. We also directly compared our RNA extraction method to several recently published noextraction methods for SARS-CoV2 detection by RT-qPCR in saliva. Although these methods greatly increase ease and throughput of RT-qPCR testing, this comes at a cost of sensitivity. Our high-volume RNA extraction protocol allows for a 30-fold concentration of the saliva sample in addition to the inactivation and removal of enzymatic inhibitors present in saliva. In a comparison utilizing saliva spiked with virus, our high-volume RNA extraction protocol led to the detection of at least 56 times more viral RNA than the use of inactivated saliva as input.

To maximize the sensitivity of our serology measurements, we employed serology assays that we recently developed using Single Molecule Array (Simoa) technology ${ }^{7}$. The high sensitivity of these assays is particularly advantageous in saliva, where antibody levels are known to be low ${ }^{19,30,34}$. We have also demonstrated that serology measurements can be combined with direct, amplification-free detection of RNA in saliva samples. We envision that the sensitivity of the RNA assay can be further improved, for example, by adding Cas13a-based detection ${ }^{49}$. Future studies may also incorporate additional protein biomarkers in saliva to measure inflammation (cytokines, etc.) or other aspects of host response to increase the utility of multiplexed saliva diagnostics for COVID-19. 


\section{Materials and methods:}

\section{Saliva samples}

For protocol optimization and control experiments we used pooled human saliva in $1 \mathrm{~mL}$ aliquots from BiolVT. Saliva was spiked with heat-inactivated SARS-CoV2 viral particles (ATCC) at the beginning of the protocol or with SARS-CoV2 synthetic RNA (Twist Bioscience) after Proteinase K treatment. COVID-19 positive and negative saliva samples were obtained from adult patients presenting to Massachusetts General Hospital (MGH). Seven samples were from patients who tested negative for SARS-CoV2 using RT-qPCR from nasopharyngeal (NP) swabs and 9 samples were from patients who tested positive for SARS-CoV2 using RT-qPCR from NP swabs. Pre-pandemic control samples were purchased from BiolVT. Samples were centrifuged at $13,150 \times \mathrm{g}$ at $4^{\circ} \mathrm{C}$ for $10 \mathrm{~min}$. The supernatant was removed and used for RNA and antibody detection. All saliva samples were collected under approval of the Mass General Brigham Institutional Review Board for Human Subjects Research.

\section{RNA extraction using custom protocol}

RNA extractions were done in 96-well LoBind PCR plates (Eppendorf) or 2000 $\mu \mathrm{L}$ Deepwell plates (Eppendorf). Proteinase K and SDS were added to one volume of saliva $(30 \mu \mathrm{L}$ or $300 \mu \mathrm{L})$ to a final concentration of $0.5 \%$ SDS and $20 x$ Proteinase K (New England Biolabs) and saliva was incubated at $65^{\circ} \mathrm{C}$ for 30 minutes. Two volumes of lysis buffer consisting of $6 \mathrm{M}$ Guanidinium Thiocyanate (Millipore Sigma) and 0.5\% Triton X-100 (ThermoFisher Scientific) were then added and mixed by pipetting. Sera-Mag Carboxylate-Modified Magnetic Beads (Cytiva), used at $10 \mu \mathrm{L}$ per reaction, were washed twice in $1 \mathrm{~mL}$ water and resuspended in an equivalent volume of lysis buffer. Beads in lysis buffer $(10 \mu \mathrm{L})$ were then added to each reaction. Three volumes of isopropyl alcohol (Millipore Sigma) were added to each reaction, and the samples were mixed well by pipetting up and down ten times. Samples were incubated for five minutes at room temperature to allow RNA to bind to beads, and then placed on a magnet. When solution cleared (approximately 2 minutes for small-volume extraction or 15-20 minutes for large-volume extraction), with the plate still on the magnet, supernatant was removed. When using low-volume $(200 \mu \mathrm{L})$ plates: beads were washed twice with $150 \mu \mathrm{L}$ of $70 \%$ ethanol. Ensuring that all of the ethanol is removed, RNA was then eluted using $10 \mu \mathrm{L}$ of nuclease-free water. When using high-volume (deep-well) plates: $150 \mu \mathrm{L}$ of $70 \%$ ethanol was added and beads were resuspended in $70 \%$ ethanol off of the magnet and transferred to a PCR plate. The 
medRxiv preprint doi: https://doi.org/10.1101/2021.01.25.21249679; this version posted January 26, 2021. The copyright holder for this preprint (which was not certified by peer review) is the author/funder, who has granted medRxiv a license to display the preprint in perpetuity.

It is made available under a CC-BY-NC-ND 4.0 International license .

PCR plate was then placed on magnet and supernatant was removed. Another $150 \mu \mathrm{L}$ of $70 \%$ ethanol was added to the deep-well plate to get any residual beads and transferred to beads on the PCR plate. One last $70 \%$ ethanol wash step was then performed on the PCR plate and all $70 \%$ ethanol removed. RNA was eluted using either $20 \mu \mathrm{L}$ (for recovery experiments) or $10 \mu \mathrm{L}$ (for comparison to other methods) of nuclease-free water.

\section{RNA extraction comparison}

For all comparison experiments, pooled human saliva spiked in with heat-inactivated virus at 50 particles $/ \mu \mathrm{L}$ was used. For the comparison of the custom protocol to the commercial kit, ThermoFisher Scientific MagMAX Viral/Pathogen Nucleic Acid Isolation was used according to manufacturer's protocol with either $200 \mu \mathrm{L}$ input volume or $400 \mu \mathrm{L}$ input volume and $50 \mu \mathrm{L}$ elution volume. For the comparison to the no-extraction protocols, saliva with virus was transferred to PCR strip tubes for inactivation. For the $95^{\circ} \mathrm{C}$ protocol, saliva was heated at $95^{\circ} \mathrm{C}$ for 5 minutes. For the TCEP protocol, Tris(2-carboxyethyl)phosphine hydrochloride (Millipore Sigma) was dissolved in water, EDTA was added to a final concentration of $0.1 \mathrm{M}$, and $\mathrm{NaOH}$ was added until the TCEP solution reached a $\mathrm{pH}$ of 8 . This TCEP solution was added 1:100 to saliva and heated at $95^{\circ} \mathrm{C}$ for 5 minutes. For the SalivaDirect Proteinase $\mathrm{K}$ protocol, $50 \mu \mathrm{L}$ saliva was added to $6.25 \mu \mathrm{L}$ of Proteinase K, Molecular Biology Grade (New England Biolabs). The tube was then vortexed at 3200 RPM for 1 minute and heated at $95^{\circ} \mathrm{C}$ for 5 minutes. For all noextraction methods, $8.2 \mu \mathrm{L}$ of inactivated saliva was used as input into the RT-qPCR.

\section{$R T-q P C R$}

Viral RNA was quantified using Luna Universal Probe One-Step RT-qPCR kit (New England Biolabs) according to the manufacturer's protocol in a CFX96 Real-Time Detection System (BioRad). All RT-qPCR reactions were performed using CDC N1 primers ${ }^{50}$ (IDT), targeting the $\mathrm{N}$ gene of SARS-CoV2, used at a final concentration of $0.4 \mu \mathrm{M}$ with the probe at $0.2 \mu \mathrm{M}$.

Sequences are: Forward: GACCCCAAAATCAGCGAAAT, Reverse:

TCTGGTTACTGCCAGTTGAATCTG, Probe: FAM-ACCCCGCATTACGTTTGGTGGACC$B H Q 1$. For each reaction, $8.2 \mu \mathrm{L}$ (of purified RNA or inactivated saliva) input was used together with $10 \mu \mathrm{L}$ Luna Master Mix, $1 \mu \mathrm{L}$ Luna Enzyme Mix, and $0.8 \mu \mathrm{L}$ primer/probe mix. For each RNA extraction optimization or comparison experiment, an aliquot of SARS-CoV2 synthetic RNA (Twist Bioscience) or heat-inactivated SARS-CoV2 viral particles (ATCC) was run on the same RT-qPCR plate. Differences in RT-qPCR cycle threshold $(\mathrm{Ct})$ values between the sample and 
in-plate control (ex. 10,000 viral particles) were calculated using the equation:

Relative RNA Level $=2^{-\Delta C t}$.

\section{Simoa Serology Measurements in Saliva}

SARS-CoV2 serological measurements were performed as previously described ${ }^{7}$. The saliva samples were 100-fold diluted in ThermoFisher Scientific StartingBlock T20 Blocking Buffer (PBS) with 1X Halt Protease Inhibitor Cocktail (ThermoFisher Scientific) with EDTA. The Simoa assays were performed on the automated HD-X Analyzer (Quanterix). IgG, IgA and lgM against RBD, S1, spike, and nucleocapsid were measured in duplicate and the average AEB (average enzyme per bead) for each interaction was calculated.

\section{Direct SARS-CoV2 RNA detection with Simoa}

A Simoa assay against SARS-CoV2 RNA was developed as described in detail in the Supplementary Information. Briefly, LNA capture probes were coupled to dye-encoded carboxylmodified paramagnetic beads using EDC and Sulfo-NHS ${ }^{48}$. The beads were incubated with the sample at $60^{\circ} \mathrm{C}$ for 2 hours to allow hybridization of the LNA probes with the target RNA molecules. The beads were washed and incubated with biotinylated detector probes for 30 minutes. After additional washes, the beads were incubated with streptavidin- $\beta$-galactosidase $(S \beta G)$ for 20 minutes. The beads were washed, resuspended in fluorogenic resorufin $\beta$-Dgalactopyranoside (RGP) and loaded into a microwell array for imaging. The first two steps were performed offline in a 96-well plate, whereas the rest of the assay was performed on the HD-X Analyzer (Quanterix).

\section{Acknowledgments:}

The authors acknowledge funding from the Bill and Melinda Gates Foundation for this work. The MGH/MassCPR COVID biorepository was supported by a gift from Ms. Enid Schwartz, by the Mark and Lisa Schwartz Foundation, the Massachusetts Consortium for Pathogen Readiness and the Ragon Institute of MGH, MIT and Harvard.

\section{Competing interests:}

DRW has a financial interest in Quanterix Corporation, a company that develops an ultrasensitive digital immunoassay platform. He is an inventor of the Simoa technology, a founder of the company and also serves on its Board of Directors. His interests were reviewed and are 
medRxiv preprint doi: https://doi.org/10.1101/2021.01.25.21249679; this version posted January 26, 2021. The copyright holder for this preprint (which was not certified by peer review) is the author/funder, who has granted medRxiv a license to display the preprint in perpetuity.

It is made available under a CC-BY-NC-ND 4.0 International license .

managed by BWH and Partners HealthCare in accordance with their conflict of interest policies.

GMC commercial interests: http://arep.med.harvard.edu/gmc/tech.html

\section{References:}

1. Ravi N, Cortade DL, Ng E, Wang SX. Diagnostics for SARS-CoV-2 detection: A comprehensive review of the FDA-EUA COVID-19 testing landscape. Biosens Bioelectron. 2020;165:112454. doi:10.1016/j.bios.2020.112454

2. $\quad$ Feng W, Newbigging AM, Le C, et al. Molecular Diagnosis of COVID-19: Challenges and Research Needs. Anal Chem. 2020;92(15):10196-10209. doi:10.1021/acs.analchem.0c02060

3. Venter M, Richter K. Towards effective diagnostic assays for COVID-19: a review. J Clin Pathol. 2020;73(7):370-377. doi:10.1136/jclinpath-2020-206685

4. Tang Y-W, Schmitz JE, Persing DH, Stratton CW. Laboratory Diagnosis of COVID-19: Current Issues and Challenges. J Clin Microbiol. 2020;58(6). doi:10.1128/JCM.00512-20

5. Wiersinga WJ, Rhodes A, Cheng AC, Peacock SJ, Prescott HC. Pathophysiology, Transmission, Diagnosis, and Treatment of Coronavirus Disease 2019 (COVID-19): A Review. JAMA. 2020;324(8):782-793. doi:10.1001/jama.2020.12839

6. Sethuraman N, Jeremiah SS, Ryo A. Interpreting Diagnostic Tests for SARS-CoV-2. JAMA. 2020;323(22):2249-2251. doi:10.1001/jama.2020.8259

7. Norman M, Gilboa T, Ogata AF, et al. Ultrasensitive high-resolution profiling of early seroconversion in patients with COVID-19. Nat Biomed Eng. Published online 2020. doi:10.1038/s41551-020-00611-x

8. Li Y, Xia L. Coronavirus Disease 2019 (COVID-19): Role of Chest CT in Diagnosis and Management. AJR Am J Roentgenol. 2020;214(6):1280-1286. doi:10.2214/AJR.20.22954

9. Wang Y, Kang H, Liu X, Tong Z. Combination of RT-qPCR testing and clinical features for diagnosis of COVID-19 facilitates management of SARS-CoV-2 outbreak. J Med Virol. 2020;92(6):538-539. doi:10.1002/jmv.25721

10. Savvides C, Siegel R. Asymptomatic and presymptomatic transmission of SARS-CoV-2: A systematic review. medRxiv Prepr Serv Heal Sci. Published online June 17, 2020:2020.06.11.20129072. doi:10.1101/2020.06.11.20129072

11. He X, Lau EHY, Wu P, et al. Temporal dynamics in viral shedding and transmissibility of COVID-19. Nat Med. 2020;26(5):672-675. doi:10.1038/s41591-020-0869-5

12. To KK-W, Tsang OT-Y, Leung W-S, et al. Temporal profiles of viral load in posterior oropharyngeal saliva samples and serum antibody responses during infection by SARSCoV-2: an observational cohort study. Lancet Infect Dis. 2020;20(5):565-574. doi:10.1016/S1473-3099(20)30196-1

13. Zou L, Ruan F, Huang M, et al. SARS-CoV-2 Viral Load in Upper Respiratory Specimens of Infected Patients. N Engl J Med. 2020;382(12):1177-1179.

doi:10.1056/NEJMc2001737 
medRxiv preprint doi: https://doi.org/10.1101/2021.01.25.21249679; this version posted January 26, 2021. The copyright holder for this preprint (which was not certified by peer review) is the author/funder, who has granted medRxiv a license to display the preprint in perpetuity. It is made available under a CC-BY-NC-ND 4.0 International license .

14. Wölfel R, Corman VM, Guggemos W, et al. Virological assessment of hospitalized patients with COVID-2019. Nature. 2020;581(7809):465-469. doi:10.1038/s41586-0202196-X

15. Yongchen Z, Shen H, Wang X, et al. Different longitudinal patterns of nucleic acid and serology testing results based on disease severity of COVID-19 patients. Emerg Microbes Infect. 2020;9(1):833-836. doi:10.1080/22221751.2020.1756699

16. Lauer SA, Grantz KH, Bi Q, et al. The Incubation Period of Coronavirus Disease 2019 (COVID-19) From Publicly Reported Confirmed Cases: Estimation and Application. Ann Intern Med. 2020;172(9):577-582. doi:10.7326/M20-0504

17. Arons MM, Hatfield KM, Reddy SC, et al. Presymptomatic SARS-CoV-2 Infections and Transmission in a Skilled Nursing Facility. N Engl J Med. 2020;382(22):2081-2090. doi:10.1056/NEJMoa2008457

18. Bi Q, Wu Y, Mei S, et al. Epidemiology and transmission of COVID-19 in 391 cases and 1286 of their close contacts in Shenzhen, China: a retrospective cohort study. Lancet Infect Dis. 2020;20(8):911-919. doi:10.1016/S1473-3099(20)30287-5

19. Isho B, Abe KT, Zuo M, et al. Persistence of serum and saliva antibody responses to SARS-CoV-2 spike antigens in COVID-19 patients. Sci Immunol. 2020;5(52).

20. Wajnberg A, Amanat F, Firpo A, et al. Robust neutralizing antibodies to SARS-CoV-2 infection persist for months. Science (80- ). Published online October 28, 2020:eabd7728. doi:10.1126/science.abd7728

21. Iyer AS, Jones FK, Nodoushani A, et al. Persistence and decay of human antibody responses to the receptor binding domain of SARS-CoV-2 spike protein in COVID-19 patients. Sci Immunol. 2020;5(52):eabe0367. doi:10.1126/sciimmunol.abe0367

22. Rongqing Z, Li M, Song H, et al. Early Detection of Severe Acute Respiratory Syndrome Coronavirus 2 Antibodies as a Serologic Marker of Infection in Patients With Coronavirus Disease 2019. Clin Infect Dis an Off Publ Infect Dis Soc Am. 2020;71(16):2066-2072. doi:10.1093/cid/ciaa523

23. Lee Y-L, Liao C-H, Liu P-Y, et al. Dynamics of anti-SARS-Cov-2 IgM and IgG antibodies among COVID-19 patients. $J$ Infect. 2020;81(2):e55-e58.

doi:10.1016/j.jinf.2020.04.019

24. Guo L, Ren L, Yang S, et al. Profiling Early Humoral Response to Diagnose Novel Coronavirus Disease (COVID-19). Clin Infect Dis. 2020;71(15):778-785. doi:10.1093/cid/ciaa310

25. Zhao J, Yuan Q, Wang H, et al. Antibody Responses to SARS-CoV-2 in Patients With Novel Coronavirus Disease 2019. Clin Infect Dis. 2020;71(16):2027-2034. doi:10.1093/cid/ciaa344

26. Long Q-X, Liu B-Z, Deng H-J, et al. Antibody responses to SARS-CoV-2 in patients with COVID-19. Nat Med. 2020;26(6):845-848. doi:10.1038/s41591-020-0897-1

27. Amanat F, Stadlbauer D, Strohmeier S, et al. A serological assay to detect SARS-CoV-2 
medRxiv preprint doi: https://doi.org/10.1101/2021.01.25.21249679; this version posted January 26, 2021. The copyright holder for this preprint (which was not certified by peer review) is the author/funder, who has granted medRxiv a license to display the preprint in perpetuity. It is made available under a CC-BY-NC-ND 4.0 International license .

seroconversion in humans. Nat Med. 2020;26(7):1033-1036. doi:10.1038/s41591-0200913-5

28. Padoan A, Sciacovelli L, Basso D, et al. IgA-Ab response to spike glycoprotein of SARSCoV-2 in patients with COVID-19: A longitudinal study. Clin Chim Acta. 2020;507:164166. doi:https://doi.org/10.1016/j.cca.2020.04.026

29. Padoan A, Cosma C, Sciacovelli L, Faggian D, Plebani M. Analytical performances of a chemiluminescence immunoassay for SARS-CoV-2 IgM/IgG and antibody kinetics. Clin Chem Lab Med. 2020;58(7):1081-1088. doi:10.1515/cclm-2020-0443

30. Ceron JJ, Lamy E, Martinez-Subiela S, et al. Use of Saliva for Diagnosis and Monitoring the SARS-CoV-2: A General Perspective. J Clin Med. 2020;9(5):1491. doi:10.3390/jcm9051491

31. To KK-W, Tsang OT-Y, Yip CC-Y, et al. Consistent Detection of 2019 Novel Coronavirus in Saliva. Clin Infect Dis. 2020;71(15):841-843. doi:10.1093/cid/ciaa149

32. Wyllie AL, Fournier J, Casanovas-Massana A, et al. Saliva or Nasopharyngeal Swab Specimens for Detection of SARS-CoV-2. N Engl J Med. 2020;383(13):1283-1286. doi:10.1056/NEJMc2016359

33. Williams E, Bond K, Zhang B, Putland M, Williamson DA. Saliva as a Noninvasive Specimen for Detection of SARS-CoV-2. J Clin Microbiol. 2020;58(8):e00776-20. doi:10.1128/JCM.00776-20

34. Randad PR, Pisanic N, Kruczynski K, et al. COVID-19 serology at population scale: SARS-CoV-2-specific antibody responses in saliva. J Clin Microbiol. Published online October 2020:02204-02220. doi:10.1128/JCM.02204-20

35. Medeiros da Silva RC, Nogueira Marinho LC, Neto de Araújo Silva D, Costa de Lima K, Pirih FQ, Luz de Aquino Martins AR. Saliva as a possible tool for the SARS-CoV-2 detection: a review. Travel Med Infect Dis. Published online November 18, 2020:101920. doi:10.1016/j.tmaid.2020.101920

36. Sui Z, Zhang Y, Tu S, et al. Evaluation of saliva as an alternative diagnostic specimen source for SARS-CoV-2 detection by RT-dPCR. J Infect. Published online November 26, 2020:S0163-4453(20)30716-7. doi:10.1016/j.jinf.2020.11.023

37. Hettegger P, Huber J, Paßecker K, et al. High similarity of IgG antibody profiles in blood and saliva opens opportunities for saliva based serology. PLoS One. 2019;14(6):e0218456. https://doi.org/10.1371/journal.pone.0218456

38. Madar R, Straka S, Baska T. Detection of antibodies in saliva--an effective auxiliary method in surveillance of infectious diseases. Bratisl Lek Listy. 2002;103(1):38-41.

39. Yoshizawa JM, Schafer CA, Schafer JJ, Farrell JJ, Paster BJ, Wong DTW. Salivary biomarkers: toward future clinical and diagnostic utilities. Clin Microbiol Rev. 2013;26(4):781-791. doi:10.1128/CMR.00021-13

40. Tromberg BJ, Schwetz TA, Pérez-Stable EJ, et al. Rapid Scaling Up of Covid-19 Diagnostic Testing in the United States - The NIH RADx Initiative. $N$ Engl J Med. 
2020;383(11):1071-1077. doi:10.1056/NEJMsr2022263

41. Rissin DM, Kan CW, Campbell TG, et al. Single-molecule enzyme-linked immunosorbent assay detects serum proteins at subfemtomolar concentrations. Nat Biotechnol. 2010;28(6):595-599. doi:10.1038/nbt.1641

42. Ogata AF, Maley AM, Wu C, et al. Ultra-sensitive Serial Profiling of SARS-CoV-2 Antigens and Antibodies in Plasma to Understand Disease Progression in COVID-19 Patients with Severe Disease. Clin Chem. Published online September 2020. doi:10.1093/clinchem/hvaa213

43. Vogels CBF, Watkins AE, Harden CA, et al. SalivaDirect: A simplified and flexible platform to enhance SARS-CoV-2 testing capacity. medRxiv. Published online January 1 , 2020:2020.08.03.20167791. doi:10.1101/2020.08.03.20167791

44. Rabe BA, Cepko C. SARS-CoV-2 detection using isothermal amplification and a rapid, inexpensive protocol for sample inactivation and purification. Proc Natl Acad Sci. 2020;117(39):24450 LP - 24458. doi:10.1073/pnas.2011221117

45. Smyrlaki I, Ekman M, Lentini A, et al. Massive and rapid COVID-19 testing is feasible by extraction-free SARS-CoV-2 RT-PCR. Nat Commun. 2020;11(1):4812.

doi:10.1038/s41467-020-18611-5

46. Wang X, Walt DR. Simultaneous detection of small molecules, proteins and microRNAs using single molecule arrays. Chem Sci. 2020;11(30):7896-7903.

doi:10.1039/D0SC02552F

47. Gilboa T, Maley AM, Ogata AF, Wu C, Walt DR. Sequential Protein Capture in Multiplex Single Molecule Arrays: A Strategy for Eliminating Assay Cross-Reactivity. Adv Healthc Mater. 2020;n/a(n/a):2001111. doi:https://doi.org/10.1002/adhm.202001111

48. Cohen L, Hartman MR, Amardey-Wellington A, Walt DR. Digital direct detection of microRNAs using single molecule arrays. Nucleic Acids Res. 2017;45(14):e137-e137. doi:10.1093/nar/gkx542

49. Fozouni P, Son S, Díaz de León Derby M, et al. Amplification-free detection of SARSCoV-2 with CRISPR-Cas13a and mobile phone microscopy. Cell. Published online December 4, 2020. doi:10.1016/j.cell.2020.12.001

50. CDC. CDC 2019-Novel Coronavirus [2019-NCoV] Real-Time RT-PCR Diagnostic Panel.; 2020. https://www.fda.gov/media/134922/download 


\section{Figures:}

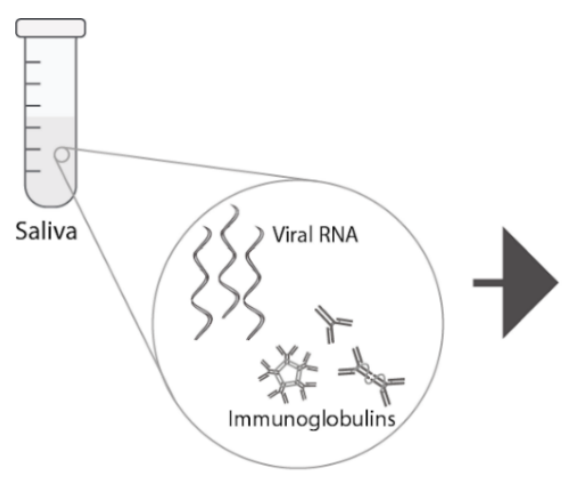

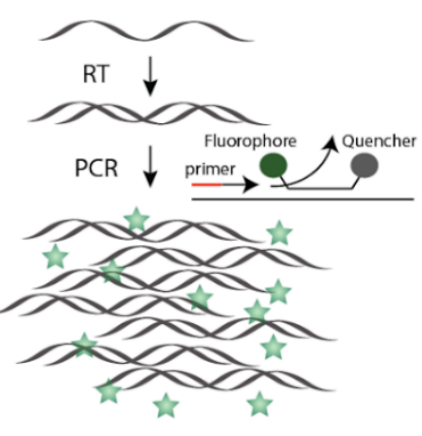

RNA quantification in RT-qPCR

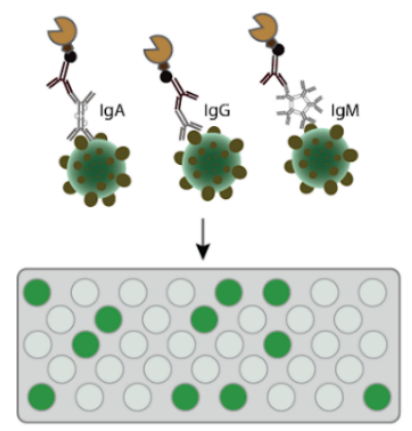

Serology profilling in Single Molecule Arrays

Figure 1: Schematic illustration of the approach for simultaneous detection of SARS-CoV2 RNA and serology in saliva samples. Saliva samples, containing both viral RNA and immunoglobulins, are split for multi-analyte detection. RNA is extracted with our custom protocol and detected using RT-qPCR. Low levels of antibodies are detected using ultrasensitive Simoa assays. 


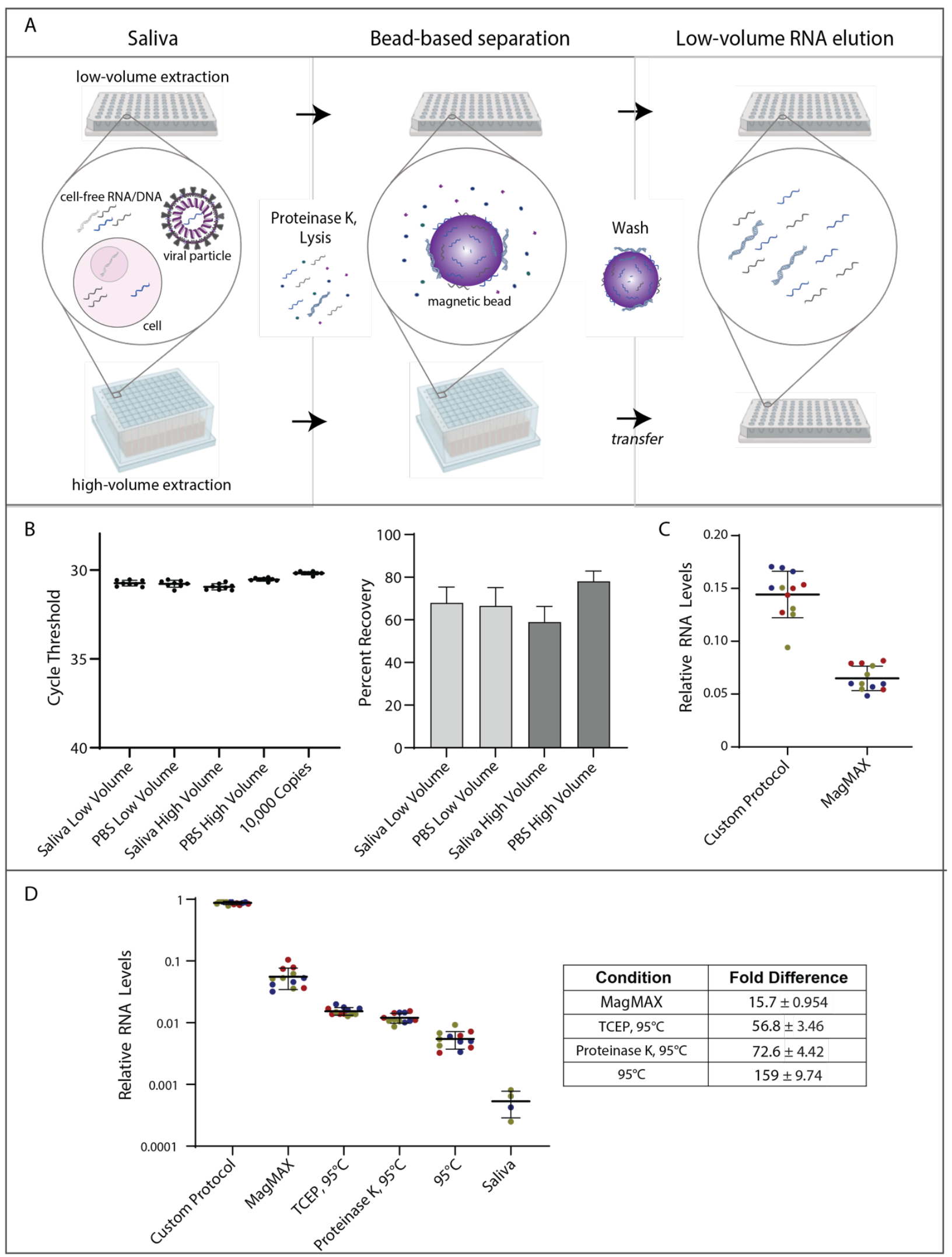


Figure 2: Custom RNA extraction protocol in saliva recovers viral RNA with high efficiency. A) Schematic representation showing our bead-based extraction protocol in low-volumes and highvolumes. B) High efficiency viral RNA recovery from PBS and saliva using custom protocol. PBS or saliva (30 $\mathrm{L}$ for low volume or $300 \mu \mathrm{L}$ for high volume) were spiked with 10,000 copies of synthetic SARS-CoV2 RNA (RNA). Our custom RNA extraction protocol was performed, and extracted RNA was compared to equivalent input amounts of spiked in RNA using RT-qPCR. Recovery of RNA is calculated as RNA level of extracted SARS-CoV2 RNA relative to spike in amount. C) Direct comparison of custom protocol with commercial kit using same volume. RNA was extracted from $200 \mu \mathrm{L}$ of saliva with 50 particles/ $\mu \mathrm{L}$ of heat-inactivated virus and eluted into $50 \mu \mathrm{L}$ using either our custom protocol or the MagMAX kit and quantified by RT-qPCR. D) Comparison of extraction and extraction-free methods. For all methods, saliva spiked with 50 viral particles/ $\mu \mathrm{L}$ was used and the same volume of inactivated saliva or eluted RNA was compared by RT-qPCR. For comparison of RNA extraction methods, maximum input volume $(400 \mu \mathrm{L}$ for MagMAX vs. $300 \mu \mathrm{L}$ for custom) and minimal elution volume $(50 \mu \mathrm{L}$ for MagMAX vs. $10 \mu \mathrm{L}$ for custom) were used. Relative RNA Levels (log scale) represent RT-qPCR quantification for each condition relative to spike-in aliquot on same RT-qPCR plate. Fold-differences for Relative RNA Levels measured in the Custom Protocol relative to the other conditions are summarized in the table. For the saliva control (no-inactivation), 8/12 replicates had no detectable levels of RNA and were not plotted. Four replicates were repeated across three different days for each condition (different colors represent different days). Error bars for all figures indicate Standard Deviation. 


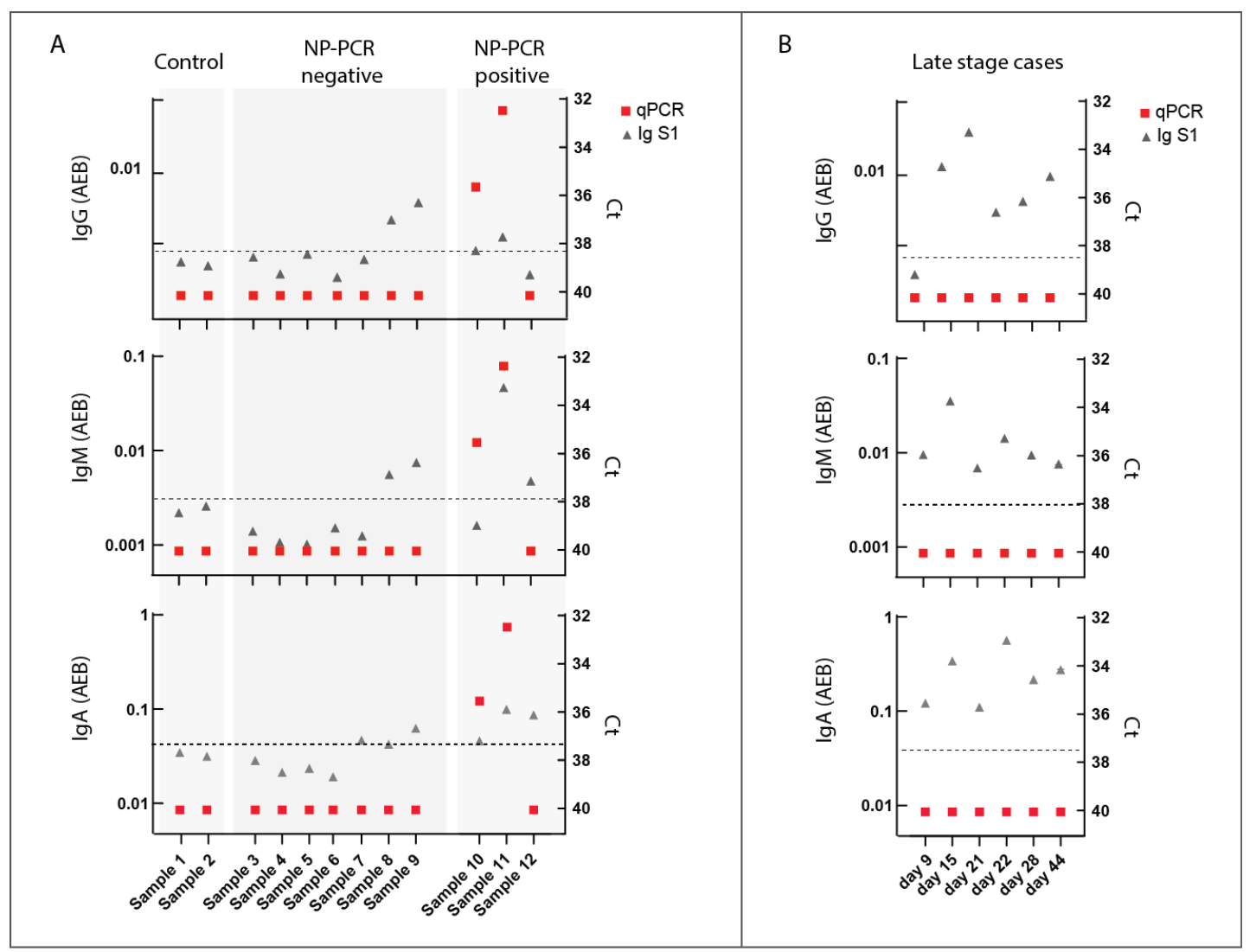

Figure 3: Detection of SARS-CoV2 RNA and serology from the same saliva sample of hospitalized COVID-19 patients. A) Detection of viral RNA and serology from saliva patient samples on day of hospitalization. RT-qPCR Ct levels (red rectangular) and Simoa serological mean AEB (average enzyme per bead) levels (gray triangles) for $\lg \mathrm{G}$, IgM, and $\lg \mathrm{A}$ against $\mathrm{S} 1$ subunit. The samples were divided into three groups: pre-pandemic control samples (left, n=2), saliva samples from patients who tested negative by RT-qPCR from nasopharyngeal swabs (NP-PCR negative, middle, $n=7$ ) and saliva samples from patients who tested positive by RTqPCR from nasopharyngeal swabs (NP-PCR positive, right, $n=3$ ). Black dotted lines indicate the antibodies threshold above the control samples. Conditions were signal is undetected are set to $\mathrm{Ct}=40$. B) Detection of viral RNA and serology from saliva patient samples several days (between 9 and 44) after hospitalization. Conditions were signal is undetected are set to $\mathrm{Ct}=$ 40. 